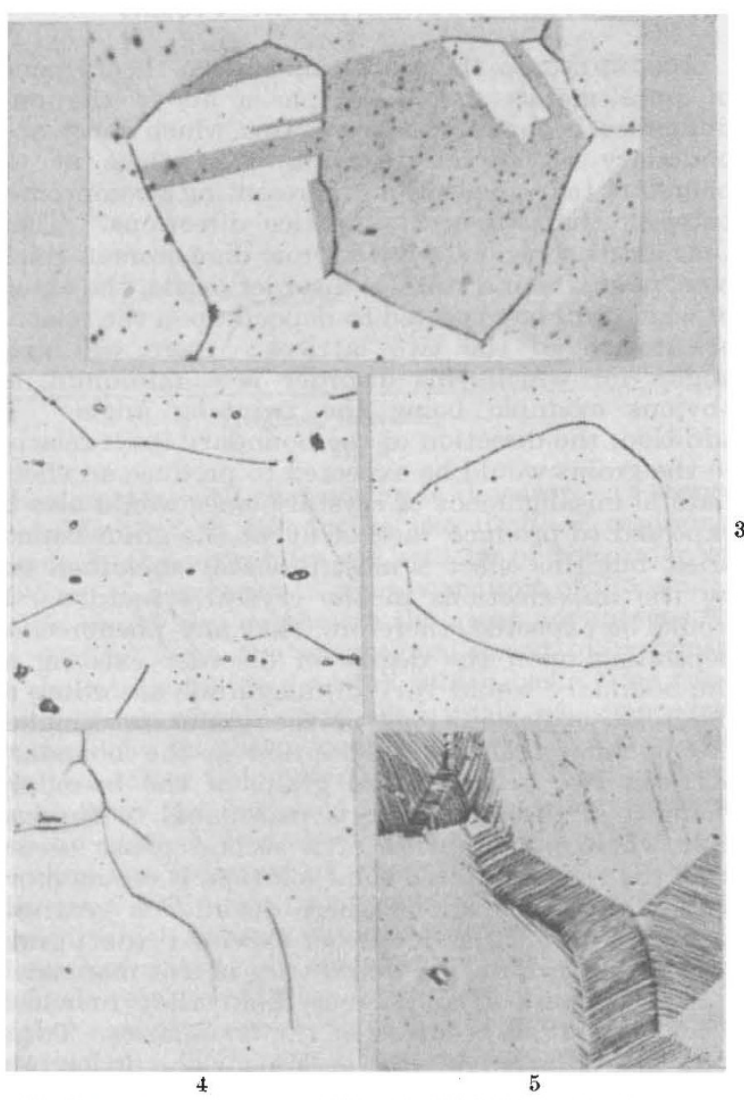

(1) COPPER-BERYLLIUM ALLOY, ELECTROLYTICALLY POLISHED, CHEMICALLY ETCHED. $\times 1,000$

(2) ALUMINIUM-MAGNESIUM ALLOY, BLECTROLYTICALLY POLISHED, CHEMICALIY ETCHED. $\times 500$

(3) COPPER-BERYLLIUM ALLOY, ELECTROLYTICALLY POLISHED CHEMICALLY ETCHED. $\times 750$

(4) SILVER, ELECTROLYTIOALLY POLISHED, THERMALLY ETCHEI IN NITROGEN. $\times 200$

(5) SILVER (SAME FIELD AS 4 AFTER SUBSEQUENT HEATING IN AIR). $\times 200$

show similar variations to those shown by the precipitation in Figs. 1, 2 and 3. Fig. 4 shows the appearance of a specimen of silver after alternate heating in nitrogen and air at $920^{\circ} \mathrm{C}$., the last heating being in nitrogen. There is one example of a grain boundary groove which changes its appearance with change of direction, and three cases of grooves which terminate abruptly. Fig. 5, of the same surface after a subsequent heating in air, reveals the presence of twins, showing that abrupt termination of the boundary groove is due to the change in orientation produced by twinning.

In the case of thermally etched silver, since the etching takes place on a prepared surface, the orientation of the boundary relative to the free surface would be expected to have an effect. This might contribute to the change in nature of the boundary groove where it changes direction, but not to the abrupt change where twinning occurs. The variations in precipitation are, of course, not subject to the effect of the surface, since precipitation occurs in the body of the material before the surface is prepared.
P. J. E. ForSYTH
R. KING
G. J. Metcalfe
B. Chalmers

Royal Aircraft Establishment,

Farnborough, Hants. Oct. 25.

${ }^{1}$ Shuttleworth, R., King, R., and Chalmers, B., Nature, 158, 482 (1946).

\section{Fungistatic Activity of Ethylenic and Acetylenic Compounds}

IN a recent discussion of the lachrymatory activity of some ethylenic compounds, Dixon and Needham ${ }^{1}$ have suggested that lachrymatory properties are conferred by certain substituent groups (ketone, aldehyde, ester, nitro-, etc.) which polarize the adjacent olefinic linkages, rendering them reactive towards nucleophilic reagents.

We have studied the fungistatic activity of a considerable number of ethylenic and acetylenic compounds and had developed a similar theory to account for fungistatic activity. In view of Dixon and Needham's results, and observations we have made on bacteriostatic activity, we now consider that it may be more correct to suppose that substituent groups which tend to attract electrons confer general toxicity on living cells, the specific type of toxicity being conditioned by other factors.

The lack of parallelism between fungistatic activity and physiological effects on man (see examples in accompanying table) affords support for this view.

\begin{tabular}{lcl}
\multicolumn{1}{c}{ Compound } & $\begin{array}{c}\text { Fungistatic } \\
\text { activity* }\end{array}$ & Physiological effect on man \\
$\beta$-Nitrostyrene & $6 \cdot 25$ & Powerful sternutator \\
4-Methoxy- $\beta$-nitrostyrene & $7 \cdot 8$ & Non-irritant \\
Cinnamic aldehyde & $125 \cdot 0$ & Pleasant aromatic odour \\
Ethyl acrylate & $>1000 \cdot 0$ & Unpleasant pungent odour \\
Ethyl propiolate & $>1000 \cdot 0$ & Highly lachrymatory \\
* Expressed as least concentration $(\mu \mathrm{gm}$ & ./ml. $)$ inhibiting germination \\
of Botrytis allii conidia. &
\end{tabular}
of Botrytis allii conidia.

In one respect our observations have been similar to those of Dixon and Needham. Just as they found acids to be less lachrymatory than their corresponding mothyl or ethyl esters, so we have found them to be less fungistatically active. We do not consider that this is due to the carboxyl group being ineffective in producing the necessary electromeric displacement, as suggested by Dixon and Needham. On the contrary, there is considerable evidence ${ }^{2-5}$ that the carboxyl group (though not the carboxyl ion) is a group which attracts electrons, and we consider that these observed differences in activity are more readily explained by the well-known greater permeability of living cells to esters than to acids.

Our results will shortly be published in detail elsewhere.
P. W. Brian
J. F. Grove
J. C. McGowan

Butterwick Research Laboratories,

Imperial Chemical Industries, Ltd.,

The Frythe,

Welwyn, Herts.

${ }^{1}$ Dixon, M., and Needham, D. M., Nature, 158, 432 (1946).

2 Robinson, R., "Outline of an Electrochemical (Electronic) Theory of the Course of Organic Reactions" (Institute of Chemistry, London, 1932), 49.

${ }^{3}$ Fieser, L. F., and Fieser, N., "Organic Chemistry"' (Boston, 1944),

'Ingold, C. K., and Ingold, E. H., J. Chem. Soc., 2354 (1931).

${ }^{5}$ McGowan, J. C., Chem. and Ind., 55, 607 (1936).

\section{Antibacterial Activity in Members of the Native Australian Flora}

WE are carrying out a survey of the native flora of Australia for the presence of antibacterial substances. Much of this flora is unique and may well provide new and interesting antibiotics.

Atkinson and Rainsford ${ }^{1}$ recorded the results of a preliminary investigation of 410 species of flowering plant native to Australia, and afterwards another 